\title{
Doing good or doing nothing? Celebrity, media and philanthropy in China
}

\author{
Jonathan Hassid and Elaine Jeffreys \\ Department of Political Science, Iowa State University, USA and Faculty of Arts and Social Sciences, \\ University of Technology Sydney, Australia
}

\begin{abstract}
Based on a statistical analysis of 91 celebrity-endorsed charities in the People's Republic of China, this paper challenges the popular assumption that celebrity involvement with not-forprofit organisations attracts extensive media coverage. Although China is the largest media market in the world, previous studies of celebrity philanthropy have been conducted almost exclusively in a Western context. Such studies argue passionately for and against the role that celebrities can play in attracting attention to humanitarian causes, focusing on the activities of Western celebrities, corporations and consumers as essential or problematic promoters and providers of aid to people in developing countries. We show that - in China, at least - most of this debate is overblown. Rather than arguing in favour of or against celebrity philanthropy, we provide statistical results suggesting that celebrity endorsement has very little impact on press coverage of charities.
\end{abstract}

Keywords: celebrity; charity; China; media; not-for-profit; philanthropy

\section{Introduction}

Celebrity activism is an ever-growing, internationally visible phenomenon-yet the impact of these high-profile humanitarians on public awareness, government support, and mobilization of resources remains under-researched. ${ }^{1}$

There has been a proliferation of celebrity within development publicity, media events and representations, which has received little attention from development scholars. ${ }^{2}$ 
Cultural Studies has not devoted much notice to one of the keynote developments in modern culture over the last 30 years: namely, the rise of various charity projects fronted and, in the public mind, defined by celebrities. ${ }^{3}$

Celebrity involvement in humanitarian causes has become a focus of academic investigation in recent years, chiefly because celebrity philanthropy is viewed as a growing and highly mediatised phenomenon. Supporters argue that leveraging 'fame' helps to raise the public profile of a given social issues campaign and its host organisation by bringing extra media coverage, attracting new audiences, demystifying campaign issues, encouraging sponsorship and raising public awareness. ${ }^{4}$ Critics insist that celebrity-endorsed philanthropy bolsters consumerism and corporate capitalism because it is driven by media desires for a story, the imperatives of the celebrity industry, and disguises the exploitative nature of trade and business relationships. ${ }^{5}$ Despite evident disagreement, both critics and supporters of celebrity philanthropy generally focus on the activities of Western celebrities, corporations, and consumers, as essential or problematic promoters and providers of aid to people in developing countries. Their different arguments are also based on the underlying assumption that celebrity philanthropy is significant because it attracts media publicity.

This paper refutes the assumption that celebrity involvement with non-profit organisations attracts extensive broadcast media coverage with reference to a statistical analysis of 91 celebrity-endorsed charities in the People's Republic of China (PRC). The PRC offers an interesting case study for comparative analysis for three reasons. First, China is the largest media market in the world. Second, the PRC is a developing country with a history of socialist-style centralised economic planning and where market-based economic reform is seen as an antidote to both entrenched poverty and totalitarianism. Finally, organised philanthropy is a new but rapidly developing phenomenon in Mainland China.

The paper first outlines the key arguments provided by supporters and critics of celebrity philanthropy. It then challenges these arguments with reference to A. Trevor Thrall et al's quantitative survey of media coverage of celebrity-endorsed charity in the USA, which we compare with a new analysis of China - the world's largest media market and a new site for celebrity and philanthropy. ${ }^{6}$ We conclude that in the context of China, at least, most of the debate surrounding celebrity philanthropy is overblown. The statistical results suggest that celebrity endorsement has very little impact on press coverage of charities. 


\section{The pros and cons of celebrity-endorsed philanthropy}

Celebrity involvement in humanitarian causes has become a focus of academic investigation in recent years because it is viewed as attracting attention and resources through media publicity to not-for-profit organisations and their causes. The United Nations (UN) explicitly cites the publicity-grabbing nature of celebrity, and the associated capacity of 'fame' to obtain much-needed resources, as the main reason for its growing ranks of celebrity ambassadors. As the website for the UN Children's Fund (UNICEF) explains:

Celebrities attract attention, so they are in a position to focus the world's eyes on the needs of children, both in their own countries and by visiting field projects and emergency programmes abroad. They can make direct representations to those with the power to effect change. They can use their talents and fame to fundraise and advocate for children and support UNICEF's mission to ensure every child's right to health, education, equality and protection. $^{7}$

Economists Matthew Bishop and Michael Green extol the 'resourceful' nature of corporate-celebrity philanthropy in a 2008 text titled Philanthrocapitalism: How the Rich Can Save the World, and Why We Should Let Them, also published under the less contentious title of Philanthrocapitalism: How Giving Can Save the World. Bishop and Green contend that Western-style democratic-capitalism is 'good' and everyone ultimately will benefit from it. In the meantime, it is fortunate that super-rich and media-savvy celebrities, for example, Microsoft co-founder Bill Gates and rock star Bono, are now using their time, money, fame and business acumen to tackle global problems, such as halting the spread of HIV/AIDS and eradicating poverty. In the words of Bishop and Green:

Philanthrocapitalists are 'hyperagents' who have the capacity to do some essential things far better than anyone else. They do not face elections every few years, like politicians, or suffer the tyranny of shareholder demands for ever-increasing profits, like CEOs of most public companies. Nor do they have to devote vast amounts of time and resources to raising money, like most heads of NGOs. That frees them to think long term, to go against conventional wisdom, to take up ideas too risky for government, to deploy substantial resources quickly when the situation demands - above all, to try something new. ${ }^{8}$ 
There is, however, no compelling reason to believe that elite philanthropists can mobilise their own capital and others' resources to resolve the world's problems in a manner that is consistently more effective in practice than the ways pursued by elected governments, fund-raising not-for-profit organisations and 'ordinary' individuals. An early example of celebrity-endorsed charity - the efforts of the supergroup 'Band Aid' to raise money for poverty relief in Ethiopia during the $1980 \mathrm{~s}$ - has been criticised for inadvertently prolonging the war in Ethiopia through the 'indiscriminate supply of humanitarian aid to the Mengistu government', aid which some people claim was diverted to purchase arms. ${ }^{9}$ Bishop and Green are simply asking for 'faith' in the market. ${ }^{10}$

Other academics argue the opposite: namely, that celebrity-endorsed philanthropy is depoliticising, promotes inequality and entails the problematic use of resources. Indeed, it appears that for some scholars 'the revolution' is back in fashion as a perceived credible solution to the problem of inequality. Cultural Studies' scholar Chris Rojek argues that the rise of 'celanthropy' (celebrity-endorsed charities) refers to an egregious form of moral regulation or social control, which encourages citizens of affluent Western liberal democracies to believe that they are making a 'real contribution' to 'feeding the world' and 'making poverty history', while ceding power to 'invisible government' and neglecting to 'address the main levers of global inequality'. ${ }^{11}$ Development scholar Ilan Kapoor similarly condemns celebrity humanitarianism on the grounds that:

It advances consumerism and corporate capitalism, and it rationalizes the very global inequality it seeks to redress; it is fundamentally depoliticizing, despite its pretensions to "activism"; and it contributes to a "postdemocratic" political landscape, which appears outwardly open and consensual, but is in fact managed by unaccountable elites. ${ }^{12}$

Rojek tells us to take off our 'rose tinted spectacles' and 'see how 'celanthropy' bolsters 'predatory, vested interests', ${ }^{13}$ while Kapoor ends his exposé of celebrity humanitarianism by calling for a 'revolutionary overthrow of the neoliberal capitalist order' ${ }^{14}$

A 2014 special issue of the Third World Quarterly on 'New Actors and Alliances in Development' similarly takes issue with philanthrocapitalism. ${ }^{15}$ Stefano Ponte and Lisa Anne Richey criticise what they call 'Brand Aid' initiatives: cause-related marketing, usually celebrity-endorsed, where the purchase of a product triggers a business donation to a not-forprofit organisation. ${ }^{16}$ A classic example is Product RED, launched by Bono in 2006, which unifies iconic brands to raise awareness and money for the Global Fund to Fight AIDS, Tuberculosis and Malaria (joinred.com). Ponte and Richey contend that such initiatives are growing in number because they enable companies to profit from enhanced media branding 
as ethical companies. ${ }^{17}$ Ponte and Richey conclude that cause-related marketing is driven by top-down corporate interests, blurs the distinction between for-profit and not-for-profit, and simplifies the history and politics of development by promoting consumption as the answer to the world's problems. ${ }^{18}$ In other words, it turns development into 'soft' rather than 'hard' news, and benefits big business by exporting Western markets and values to other countries.

Dan Brockington draws on interviews with development, media and celebrity professionals to examine the political economy of what he describes as the "celebrity-charitycorporate complex' ${ }^{19}$ Brockington contends that intense competition between international charities for funds and publicity has generated competition for access to celebrities. ${ }^{20}$ This situation has led to the creation of new professional structures, including celebrity liaison officers, staff to manage Twitter and blog followers, inter-organisational celebrity liaison officers' forums, and companies that sell information about celebrities to not-for-profit organisations. The reorientation of the not-for-profit sector to include the celebrity industry is illustrated by the Look to the Stars website, which describes itself as the 'web's number one source of celebrity charity news and information, covering what the top stars are doing to make a positive difference in the world' since 2006 (looktothestars.org).

Brockington concludes that the growing links between charities and the celebrity industry require greater scrutiny, being related to corporate interest in celebrity. ${ }^{21}$ Interviews with relevant professionals in international non-governmental organisations (NGOs) indicate that corporate sponsors are interested in charities that have celebrity connections for two key reasons. First, they value the potential for enhanced corporate branding by virtue of their association with a good cause and a celebrity. ${ }^{22}$ Second, many corporate elites apparently 'enjoy meeting publicly desirable figures in person'. ${ }^{23}$ This suggests a reorientating of the philanthropic and corporate sector towards the celebrity sector for economic reasons, involving mediatised branding, and for reasons relating to (elite) affect.

Sociologist Linsey McGoey also contends that we should be asking more questions about how philanthrocapitalists gain access to public resources and positive media publicity. ${ }^{24}$ McGoey notes that media and academic supporters of philanthrocapitalism praise celebrity CEOs for filling the gap left by the perceived 'ineptitude and waning influence of government policies', when governments are actually instrumental to the success of largescale corporate and private philanthropic endeavours. ${ }^{25}$ Contrary to the arguments of Bishop and Green, ${ }^{26}$ McGoey draws on case studies of public-private collaborations to show that philanthrocapitalists are neither taking innovative risks nor 'subsidizing gaps in development financing created by increasingly non-interventionist states'. ${ }^{27}$ McGoey concludes instead 
that governments (and taxpayers) are subsidising the philanthrocapitalists, and corporate research and development strategies. For example, Vodafone, now the world's second-largest mobile operator, was offered matching funds of nearly GBP 1 million from the UK's Department for International Development, and a Vodafone subsidiary was offered nearly USD 5 million from the Bill and Melinda Gates Foundation in 2010, to roll out M-Pesa, a system that enabled African villagers without access to conventional banking to pay bills through text message on their mobile phones. ${ }^{28}$ Vodafone is currently rolling out M-Pesa in Europe.

In summary, both supporters and critics of celebrity philanthropy contend that celebrity involvement in charitable causes is important because it attracts media publicity and therefore public attention and resources. Celebrity involvement with charities is a 'win-win' situation in the eyes of supporters because it raises public awareness and support and resources through media publicity. For critics, celebrity philanthropy entrenches Westernstyle capitalism and associated inequality, distorts policy agendas, directs resources in problematic directions, and (re)creates a privileged class of western consumers who believe that they can deliver salvation to the rest of the world by consuming the 'right product'. However, neither supporters nor critics of celebrity philanthropy typically question the underlying assumption that all these proclaimed effects flow from media publicity.

\section{Rethinking media interest in celebrity-endorsed charity and the case of China}

The assumption that celebrities help 'causes make news and capture the public's attention' is challenged by a quantitative survey of celebrity-endorsed philanthropy conducted by Thrall et $a l .{ }^{29}$ Their survey is based on a random sample of 147 celebrities from Celebopedia.net, an online encyclopaedia of entertainment and sports celebrities, and an examination of the 2006 Forbes 100, a list of the top ranking celebrities in the USA. The survey findings show that 'although most celebrities participate in various forms of advocacy, rarely do even the most famous celebrities get sustained attention from mass media news organisations for advocacyrelated activity'. ${ }^{30}$ The authors conclude that 'conventional wisdom has oversold the powers of the average celebrity to move the news machine and thereby shape policy agendas', because celebrity support for charitable causes is 'almost invisible in the overall news flow. 31

We concur that commentators may overstate the importance of celebrity-endorsed charity in terms of attracting mainstream media publicity. Figure 1 provides a graphic 
illustration of the increased use since the 1990s of the terms 'celebrity' and 'charity' (which is the more commonly used word for 'philanthropy') in Dow Jones and the world's top media outlets (with data drawn from the Factiva database). It shows that media coverage involving the use of the term 'celebrity' increased dramatically between 1983 and 2013. The term 'celebrity' obtained just under 600 hits in 1983, that figure rose to nearly 12,000 hits in 1993 and more than 79,000 hits in 2003 , reaching a high of more than 166,000 hits in 2013 . The increase in the use of the term 'charity' has been even more dramatic. The term 'charity' obtained over 700 hits in 1983, that figure rose to around 22,000 hits in 1993 and 157,000 hits in 2003, reaching a high of more than 353,000 hits in 2013.

While Figure 1 suggests a rapid growth in broadcast media interest in the two distinct subjects of 'charity' and 'celebrity', it indicates a much lower interest in 'celebrity charity'. A search for the terms 'charity' and 'celebrity' obtained less than 20 hits in 1983, more than 500 in 1993, around 5,300 in 2003, and more than 10,000 in 2013. The results for 'celebrity' and 'philanthropy' are insignificant, and hence are not included in the graph: 0 in 1983, 15 in 1993; around 150 in 2003 and around 550 in 2013.

Figure 1: Western newspaper coverage of 'celebrity' and 'charity' (1983-2013)

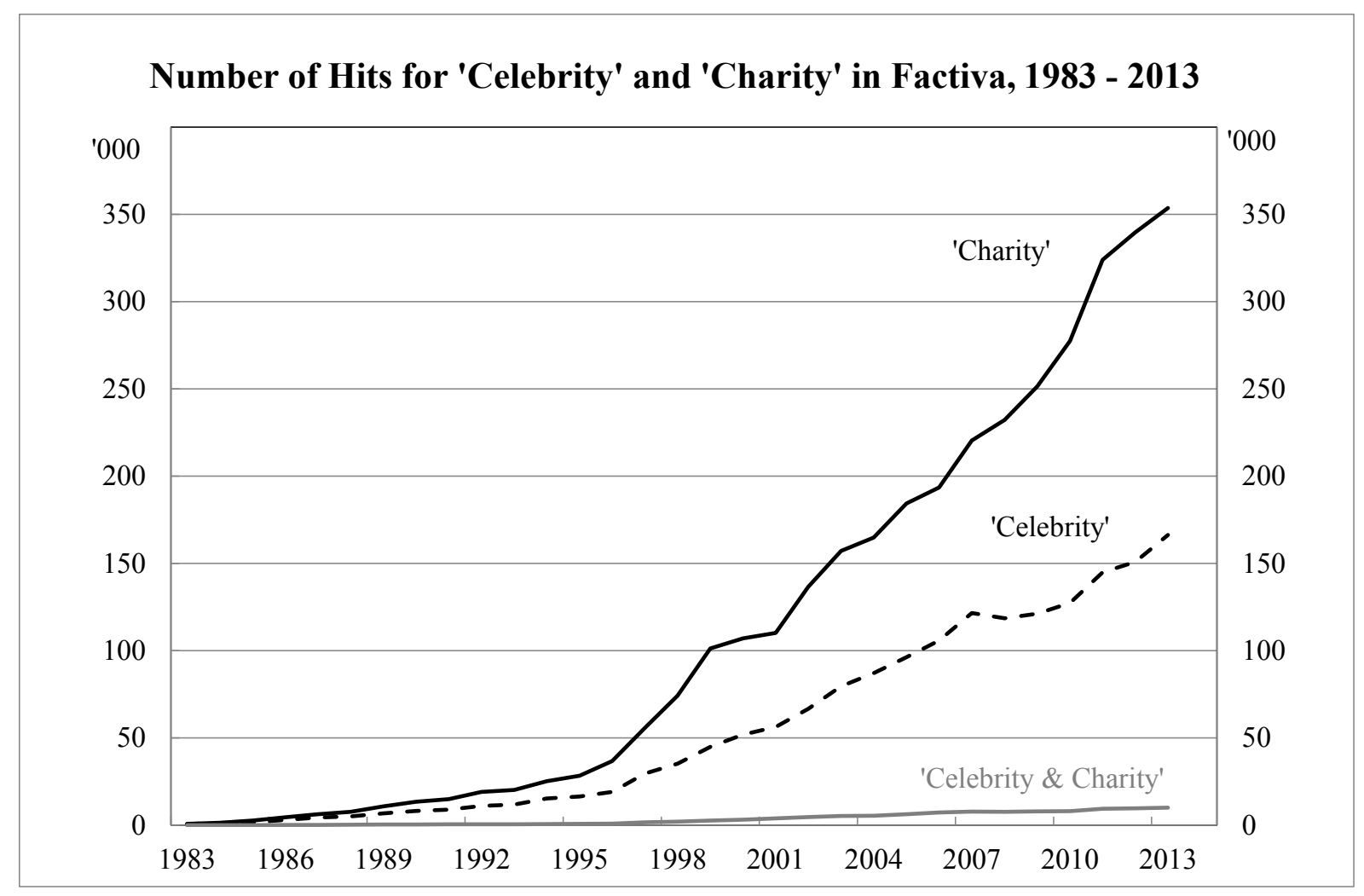

Source: Factiva.com, accessed 14 August 2014. 
One response to this apparent paradox is that celebrity involvement is important to cause-related marketing because it helps charities and corporations to reach fragmented audiences and niche markets through social media rather than through broadcast media. Thrall et al. predict that celebrity involvement with not-for-profits will grow for this reason, but add that verifying this claim is complicated by the proliferating nature of websites and digital media. ${ }^{32}$ It is further complicated, we might add, by the difficulty of obtaining reliable information about the kinds of people that engage with celebrity on social media and why, and then establishing any correlation between general viewing patterns and donations statistics and volunteering.

In any case, a UK survey of 1,000 people conducted by Media and Communications scholars Nick Couldry and Tim Markham demonstrates that engagement with celebrity culture is not typically linked 'in citizens' own accounts to issues of public concern'. ${ }^{33}$ This finding brings into question claims that the use of social media either helps to raise public awareness of development issues or reduces the political significance of those issues in the public arena. It suggests that avid consumers of celebrity culture are generally uninterested in 'hard news' and 'politics with a capital "P"', irrespective of how those issues might be defined.

We are left with the argument that celebrity involvement in humanitarian causes promotes the interests of unaccountable elites and big business. The first objection is contradicted by the prevalence of celebrity and corporate philanthropy scandals on broadcast and social media around the world. ${ }^{34}$ 'Fame' may empower entertainment and corporate celebrities to talk to an extraordinary range of audiences and political leaders on subjects about which they are not 'official experts'. However, it does not empower them to act with impunity because their lives are subject to public scrutiny.

The example of the People's Republic of China - a developing country that is in the process of establishing an indigenous not-for-profit sector at the behest of an authoritarian government -exposes the Eurocentric nature of the claim that celebrity humanitarianism simply promotes big business and is 'no substitute' for government provision of public services. ${ }^{35}$ The PRC's post-1978 abandonment of centralised economic planning and adoption of market-based reforms has lifted hundreds of millions of people out of absolute poverty and turned China into an emerging superpower, even as it has generated the new problem of inequality of wealth. In this historical and national context, 'boosting' rather than 'overthrowing' the market economy and private sector is seen as the best solution to development because the gradual dismantling of the socialist state apparatus in favour of the 
private sector has improved the quality of life for many PRC citizens. The partial privatization of the economy has provided a large proportion of Chinese citizens with increased disposable income and access to consumer goods and services, as well as more individual freedoms than at any other point in the PRC's history, despite continued controls over freedom of information.

In the Chinese context, the development of an indigenous not-for-profit sector and elite philanthropy refer to new professions, organisations and social actors that are simultaneously coming into being, largely at the behest of government to enhance public service provision. Private philanthropy was virtually eliminated in Mao-era China (19491976) as the Chinese Communist Party (CCP) eliminated opposition elite groups and the Party-state apparatus became the main conduit of public services and help for the needy. ${ }^{36}$ Soon after the foundation of the PRC in 1949, the CCP moved to consolidate power and eliminate all potential political competitors: the rural gentry, urban capitalists, opposition political figures, and religious and cultural elites, which removed the foundations of pre-1949 forms of elite philanthropy by default. Nationalization of industry and the curtailing of the monetary economy subsequently prevented private enterprise and significant private wealth accumulation. Instead, citizens of 'new China' were assigned to an employer work unit (danwei 单位) that provided basic education, health and welfare services and became the foundation of Mao-era economic and social life. This system fell apart along with the PRC's post-1978 adoption of market-based economic reforms. ${ }^{37}$ Growing demands for mobile labour, and the corollary dismantling of the rural collectives and the urban work-units, meant that the Party-state could no longer supply the rudimentary services to employees and retirees that had been the norm. The PRC Government was faced with the costly option of having to create a 'modern' welfare system from scratch: that is, a range of standardised services such as unemployment benefits, health insurance, work injury cover, disability support, maternity support, old-age retirement incomes, and so forth, that would be linked to the government's budget, and made accessible to all citizens through government, community and private service providers. ${ }^{38}$ At the same time, a stratum of newly rich political, corporate and celebrity elites has emerged in China along with the partial privatization of the economy, and the development of a commercial entertainment sector and an increasingly commercialised media. $^{39}$

The PRC Government has responded to the social demand for enhanced service provision in part by encouraging philanthropy, including volunteering, professionalised 
philanthropy and elite philanthropy. The Ninth Five-Year Plan for National Economic and Social Development (1996-2000) advocated the expansion of community-based volunteering. ${ }^{40}$ The Tenth Five-Year Plan (2001-2005) proposed developing philanthropic enterprises to supplement the inadequate social security system in the context of an aging population. ${ }^{41}$ The Eleventh Five-Year Plan (2006-2010) proposed expanding philanthropic enterprises to address rising social inequality and create an environment for more sustainable growth. ${ }^{42}$ By the time of the Twelfth Five-Year Plan (2011-2015), the PRC Government proposed massively expanding the not-for-profit sector by using tax incentives to create a system of registered private industry, trade and professional associations, and urban and rural community organisations, that will support, and perhaps even replace, many of the government's social welfare/public charity functions. ${ }^{43}$

To facilitate this agenda, the PRC Government has made substantial changes to the regulatory framework controlling the operation of philanthropy in Mainland China. These changes aim to encourage the rapid growth of an indigenous not-for-profit sector by supporting demonstrably local organisations, while continuing to restrict the role of foreign donors and actors. ${ }^{44}$ In 2012, the Central Government committed funds of CNY 200 million to promote the development of domestic NGOs (China Daily, 21 August 21, 2011, p. 3). Nineteen provinces started pilot programs allowing NGOs to register directly with civil affairs departments and, subsequently, to submit tenders for government funding, rather than having first to find a sponsoring government organisation, which was previously a major obstacle to domestic NGO registration.

Entrepreneurs and celebrities are also encouraged to support the development of philanthropy in China. The PRC's Ministry of Civil Affairs has recognised and rewarded the philanthropic efforts of entrepreneurs from the state and private sector through a system of prestigious annual charity awards since 2005. When President Hu Jintao announced the annual award winners during a highly publicised speech in December 2008, it became clear that support for the development of elite philanthropy in China came from the highest levels of the Party (Renmin Ribao, December 6, 2008). The award categories now extend beyond prizes to individual philanthropists (cishanjia 慈善家) and philanthropic businesses (cishan qiye 慈善企业) for the largest donation to charity over CNY 1 million. Other China charity awards included the category of philanthropic celebrities (cishan mingxing 慈善明星) for the first time in 2011. Celebrities are nominated for awards based on the extent of their public involvement in philanthropy; that is, for their work in promoting social awareness of 
philanthropy through media publicity (Gongyi Shibao, April 26, 2011). Hence, as in Western societies, it appears that China's celebrities are valued for the perceived important role that they can play in promoting public awareness of and support for philanthropies.

Figure 2 provides a graphic illustration of the increased use since the 2000 s of the Chinese-language terms 'cishan 慈善' (charity / philanthropy) and 'mingxing 明星' (celebrity) in China's broadcast media. Data was obtained from the China Core Newspaper Full-text Database of the China Knowledge Resource Integrated Database (CNKI), a database of around 500 Chinese newspapers since 2000 (cnki.net.cn). As with Western press coverage (see Figure 1), Figure 2 suggests a rapid growth in Chinese press coverage of the two distinct subjects of 'charity' and 'celebrity', but indicates a much lower interest in 'celebrity charity'.

Figure 2: Chinese newspaper coverage of 'celebrity' and 'charity' (2000-2013)

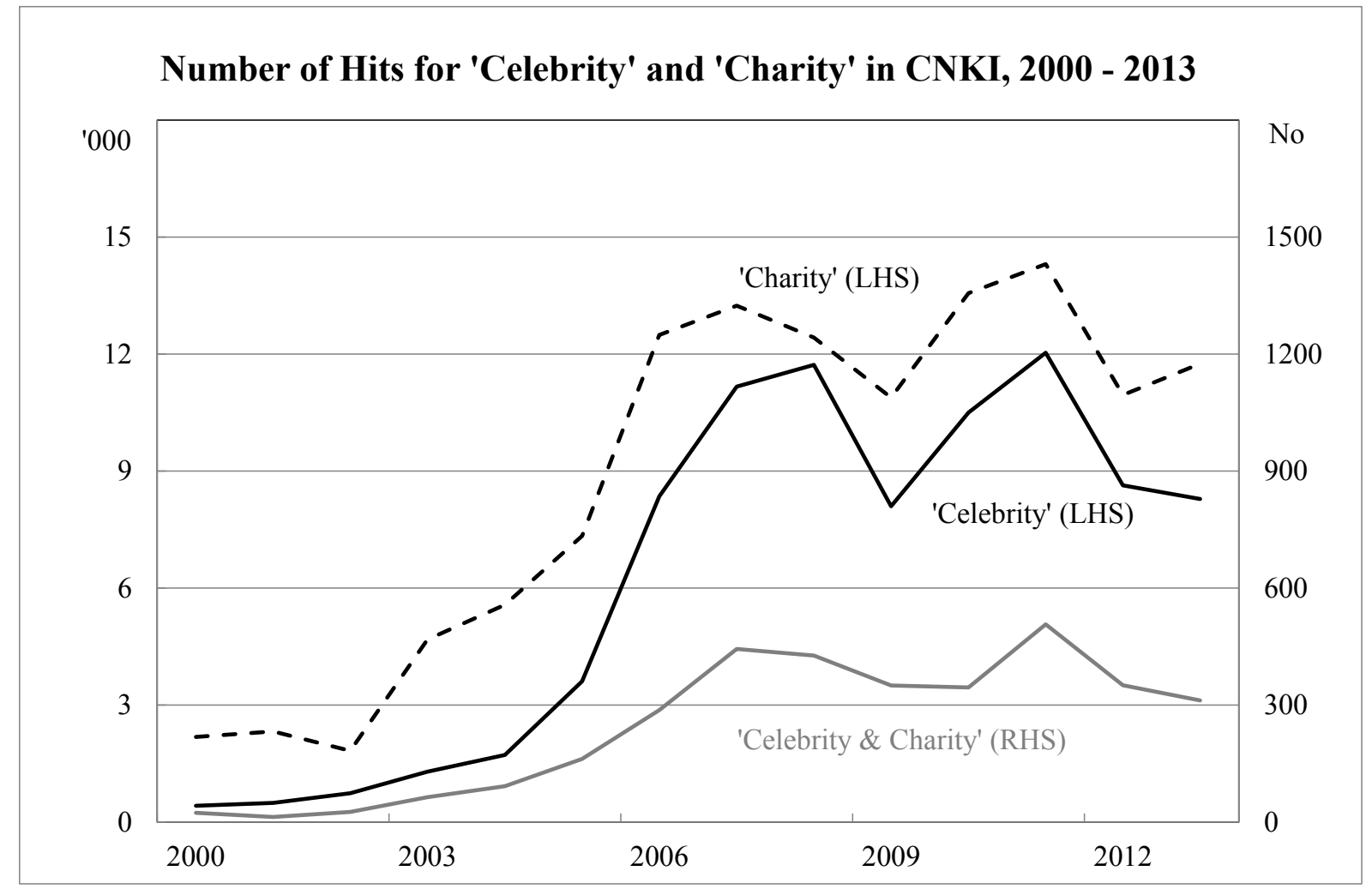

Source: Cnki.cn, accessed 14 August 2014.

The terms 'charity' and 'celebrity' received less press coverage, in terms of absolute numbers of hits, in the Chinese media (as represented in the CNKI database) than in the Western media (as represented in the Factiva database). There were over 166,000 hits for 'celebrity' in the Western media in 2013 compared to less than 12,000 in the Chinese media, and over 353,000 hits for 'charity' in the Western media in 2013 compared to less than 8,300 
in the Chinese media. Similarly, a search for the terms 'charity' and 'celebrity' obtained around 300 hits in the Chinese media in 2013 compared to around 10,000 in the Western media. Of course, a direct comparison of absolute numbers in the Western and Chinese databases needs to be treated with caution, as the scope of the Factiva database $(22,000$ newspaper sources) is much greater than that of CNKI (around 500).

Indeed, scaled by the number of hits for 'charity' in the two databases the incidence of the two terms together ('charity' and 'celebrity') was slightly higher for Chinese than for Western media (3.6 per cent compared with 2.8 per cent). This suggests that mediatised celebrity philanthropy, in proportion to coverage of philanthropy more broadly, now receives a degree of attention in China comparable to that which it receives in Western media.

\section{Methodology}

The big assumption behind most discussions of celebrity-led philanthropy is that celebrity endorsement will drive media coverage and increase a charity's subsequent visibility. To test this assumption, we obtained a list of 198 Chinese celebrities by combining five 'Top Chinese Celebrity' lists in 2011 and 2012, and then removing the names of non-mainland Chinese celebrities and all duplicate names. The five lists accessed on 1 July 2011 and again on 16 December 2012 were: Forbes' China's Top 100 Celebrities; Baidu's Today's Top 50 Female Celebrities (Jinri nümingxing paihangbang 今日女明星排行榜); Baidu’s Today’s Top 50 Male Celebrities (Jinri nanmingxing paihangbang 今日男明星排行榜); Sogou's Mainland China’s Top 60 Female Celebrities (Remen dalu nümingxing top 60 热门大陆女明 星); and Sogou's Mainland China's Top 60 Male Celebrities (Remen dalu nanmingxing top 60 热门大陆男明星). The Forbes and Baidu lists use, respectively, individual income and media exposure, and internet keyword searches, to develop hierarchical rankings of celebrities. Hence, the sample is skewed towards major celebrities, that is, celebrities who might be expected to attract more media publicity.

These 198 celebrities endorsed at least 254 charities between 2000 and 2013. From these 254 , we removed those directly related to government programs (e.g. a particular Ministry of Culture initiative) or too closely tied to corporate interests (e.g. a charitable initiative from luxury giant LVMH). We reasoned that stories about these two types of charities might reflect the overall press coverage of their parent organisations rather than media attention on the philanthropic activities themselves. ${ }^{45}$ The end result is a list of 91 
relatively 'pure' charities for ease of analysis. The full list of these 91 charities is available from Jonathan Hassid's personal website (jonathanhassid.com); the charities range from small celebrity-founded organisations like L.O.V.E. to huge government-sponsored philanthropies like Project Hope (Xiwang Gongcheng 希望工程).

We investigated these charities' media coverage by counting press coverage available in the China Core Newspaper Full-text Database. Although this database does not cover every newspaper in the country and might have some subtle biases, ${ }^{46}$ it does give an excellent picture of the level of overall press attention. Using the names of these 91 charities as a keyword, for each we counted monthly newspaper stories in a 12-month period before and after the date of first celebrity endorsement. For example, actor Huang Xiaoming provided the China Youth Foundation (Zhongguo jijinhui ertong shaonian jijinhui 中国儿童少年基金 会) with its first celebrity endorsement on 10 March 2010, so we totaled newspaper coverage in each month from March 2009 to March 2011. The end result is a list of 25 months, each containing the sum of all newspaper articles on that charity in that month. We used monthly rather than daily or weekly measures for ease of data collection and because very few charities receive regular press coverage. Indeed, the median number of newspaper articles on these charities in the entire two-year measurement period is only 5 , and the mode is 0 .

We collected monthly data for the year before the first celebrity endorsement to eliminate prior or seasonal trends that are unrelated to the impact of the celebrity endorsement itself. In other words, if a charity had ever-increasing newspaper coverage before it was endorsed simply looking at the press coverage in the months following this endorsement might give a misleading picture about the power of that endorsement.

We also reasoned that as some celebrities are more famous than others, their endorsements might carry more weight. To gauge the fame of each celebrity endorser, we obtained the number of 'hits' that appear about each on the Baidu search engine and their total number of micro-blog, or Twitter-like weibo, followers. ${ }^{47}$ We recorded whether the charity had multiple simultaneous endorsements, as some charities - the Chinese Red Cross, for example - received up to 14 celebrity endorsements at once.

After collecting all this data, we ran a series of statistical analyses to tease out the effect of celebrity endorsement of philanthropies on press coverage. In particular, we conducted two kinds of analyses: a pooled panel data model where all charities regardless of the actual dates were considered together using pseudo dates (ranging from 12 months before first endorsement to 12 months following), and a long time series model where the charities 
were considered using a timeline of actual dates. In the case of the pooled panel model, the dependent variable is the number of newspaper articles on each charity per month, while in the time series model it is the average number of newspaper articles on our selected charities in each month from July 1999 to November 2013. We augmented both models with dummy variables (described below) to estimate the impact of celebrity endorsement. The pooled panel model aims to capture the time-invariant effects of celebrity endorsement of philanthropies on press coverage, while the time series model is useful as an alternative way to cut the data and exploit variation over time.

As this is count data, normally we would be inclined to use Poisson regression for the panel data, but overdispersion in the data, ${ }^{48}$ especially on the low end with lots of charities receiving little coverage, indicates that a negative binomial regression is more appropriate. For the time series model, we averaged the number of newspaper 'hits' by month over the data collection time horizon (July 1999 to November 2013). Here, each month has data ranging from just a single charity (mostly from 1999 and late 2013) to up to 24 charities (mid-2007). For this long time series set, an ARIMA model ensures we control for any serial correlation or trends in the data and allows us to isolate the time-invariant effects of celebrity endorsement on press coverage of philanthropies.

\section{Results}

Before presenting the statistical results, it is helpful to give some context on the charities themselves. One of the big distinctions among Chinese charities is between those that can raise money directly from the public (known as public fundraising foundations or gongmu jijinhui 公募基金会) and those that cannot, the non-public fundraising foundations (feigongmu jijinhui, 非公募基金会). Funding for and from the latter comes from large donations by individuals rather than from the public directly. The biggest group in our sample comprises 63 government-affiliated charities, of which fully 60 are public fundraising institutions. The fact that over two-thirds of the sample consists of government affiliated charities represents a large departure from the West, where charities are mostly private organisations. In China, however, such a proportion is unsurprising, as many NGOs or nonstate institutions aim for state affiliation or 'codependency' to protect them from the vagaries of the authoritarian political process. ${ }^{49}$ The rest of the sample consists of: 11 international NGOs (INGOs), mostly affiliated with the UN (including the Development Program (UNDP), 
the Refugee Agency (UNHCR) and UNICEF); 9 non-public fundraising foundations founded by prominent individuals or private companies (including A-list celebrities such as Jackie Chan, Li Bingbing and Yang Lan); 4 public fundraising foundations started by celebrities or prominent CEOs; 3 public fundraising foundations established by state-owned enterprises; and 1 micro-fund. In short, the large bulk of the sample consists of those able to raise money directly from the public and affiliated directly or indirectly with the Party-state. We expected that these and other charities in the sample might attract media coverage both because of their links with government, and because censorship authorities put considerable pressure on Chinese media organisations to provide positive coverage of social issues. ${ }^{50}$

In Figure 3, we present the average number of charity-related newspaper articles over time, with a trend line indicating that newspaper coverage of charities seems to be slowly, but measurably declining. Note that for this particular figure we have removed the three major charity outliers that receive hugely disproportionate press coverage: Project Hope, the UNDP and the World Health Organization (WHO).

Figure 3: Average newspaper coverage of charities over time, with outliers removed, plus trend line and $95 \%$ confidence interval bands ${ }^{51}$

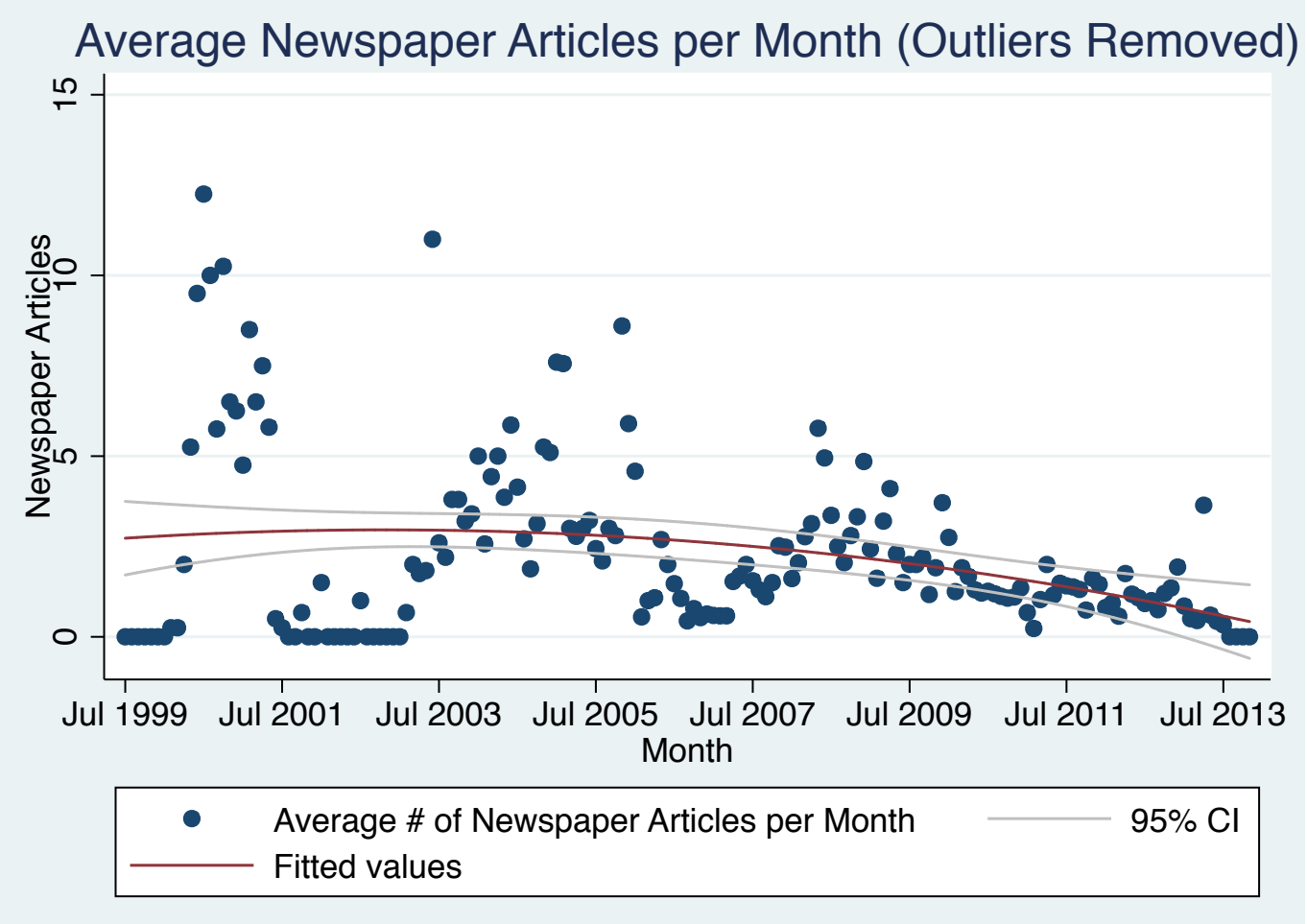

Based on this figure alone, it becomes clear that with some variations over time, newspaper coverage of the average Chinese philanthropic organisation peaked in the mid- 
2000s and has been declining ever since. If the mega charity outliers (Project Hope, the WHO and the UNDP) are included, the overall decline over time is less marked, but even here press coverage has clearly declined since the mid-2000s (see Figure 4). Note too that overall press coverage is quite modest, with the mean number of hits per month (excluding the three outliers) only around 4.4, and the median number of articles 0 . In other words, the median charity gets no press coverage at all in an ordinary month.

\section{Figure 4: Average newspaper hits per month, with trend line and $95 \%$ confidence interval bands}

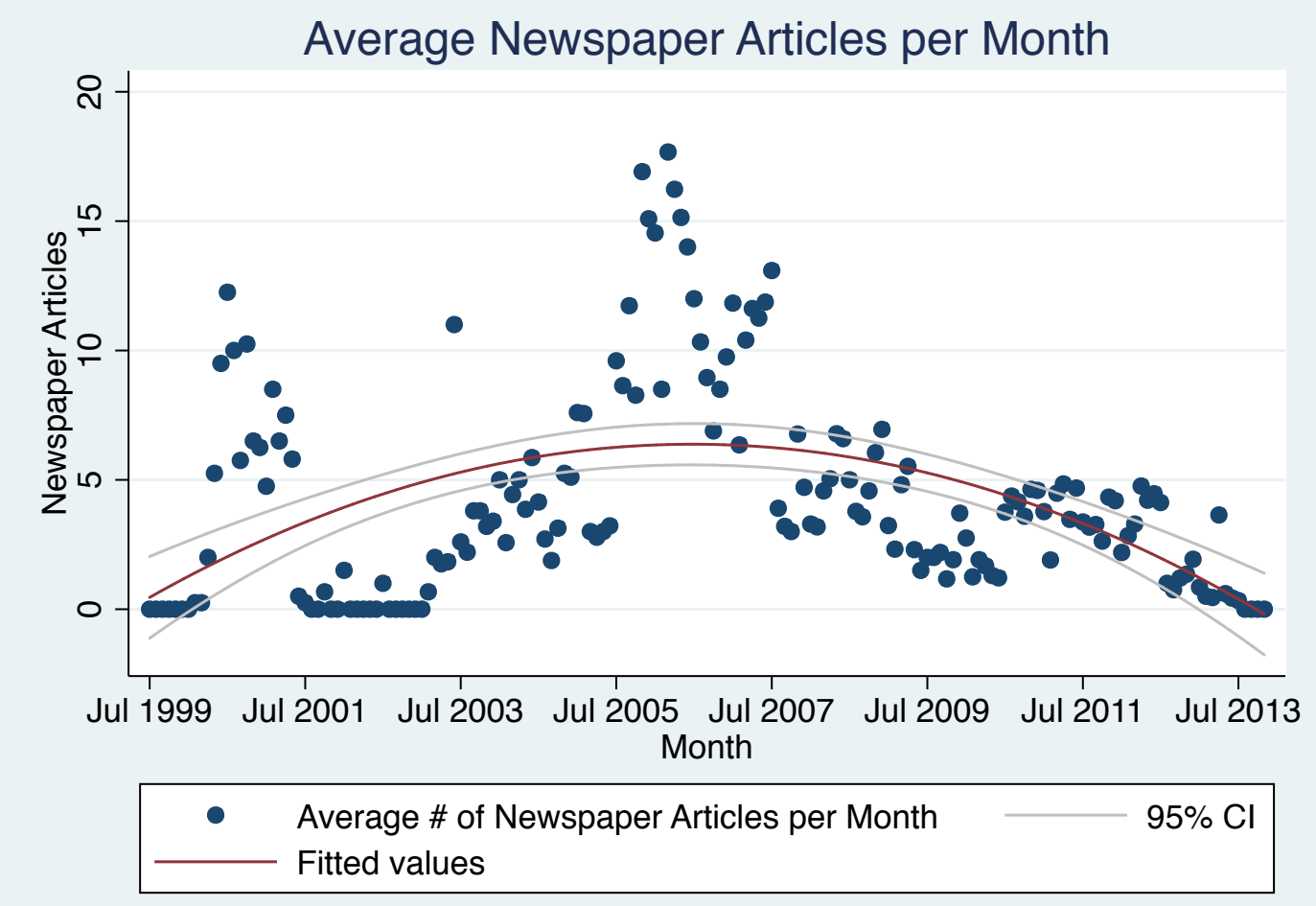

Regardless of which model we used or how the models were specified, the influence of celebrity endorsement on newspaper coverage of philanthropic organisations is quite weak. Celebrities simply do not seem to have the same sort of clout in China that other observers claim exists in Western societies. To measure the impact of celebrity endorsement of charities in China, we incorporated several independent variables into our statistical models. The first variable, 'Weibo100k', measures how many Twitter-like micro-blog followers a particular celebrity has in units of 100,000. Use of micro-blogs, or weibo (微博) in Chinese, is ubiquitous in mainland China, and here we use figures from Sina Weibo, the biggest and most popular service with over 500 million users (The New York Times, October 16, 2013, A27). Not every celebrity has a weibo account, but the large majority do, and we use this 
number as a reasonable proxy of celebrities' overall fame level. The number of followers has a huge range, from late actress Zhang Ruifang's 257 to actor Wang Baoqiang's over 52 million. ${ }^{52}$ In earlier versions of the models, we also included the number of hits on celebrities' names provided by the popular Baidu search engine, but this proved insignificant in all models and was omitted from final analysis.

A second independent variable, tested was whether charities had multiple endorsements from celebrities or just one. Most charities received only a single endorsement, but results ranged up to 13 endorsements for the Red Cross Foundation (in December 2005) and 14 endorsements for the Chinese Red Cross itself (in January 2004). We also included a dummy variable for the month of first endorsement itself, reasoning that any press impact was likely to be highest during this month and would tail off over time. Table 1 presents the results of a GLM negative binomial regression, detailing the estimated impact of these independent variables on charity newspaper coverage. ${ }^{53}$

Table 1: GLM population-averaged negative binomial regression of celebrityendorsement indicators on newspaper coverage

\begin{tabular}{llcc}
\multicolumn{1}{c}{ Variable } & Coefficient & $\begin{array}{c}\text { Estimated Standard } \\
\text { Error (cluster } \\
\text { adjusted) }\end{array}$ & p-value \\
\hline $\begin{array}{l}\text { Celebrity weibo } \\
\text { followers (in 100k } \\
\text { units) }\end{array}$ & -0.0017 & 0.0011 & 0.116 \\
\hline $\begin{array}{l}\text { Multiple } \\
\text { endorsements }\end{array}$ & $0.1183^{* *}$ & 0.0459 & 0.010 \\
\hline First month & $1.028^{* * *}$ & 0.2373 & 0.000 \\
\hline $\begin{array}{l}\text { Newspaper articles } \\
\text { from 1 month before } \\
(1 \text { lag) }\end{array}$ & $0.1515^{* *}$ & 0.0482 & 0.002 \\
\hline $\begin{array}{l}\text { Newspaper articles } \\
\text { from 2 months before } \\
(2 \text { lags })\end{array}$ & $0.1301^{*}$ & 0.0563 & 0.021 \\
\hline Constant & $-0.6149^{*}$ & 0.3137 & 0.05 \\
\hline
\end{tabular}

Note: Estimated standard errors are corrected for panel clustering, $\mathrm{n}=1720$

$* * *, * *$ and $*$ indicate significance at the $0.1 \%, 1 \%$ and $5 \%$ levels

Except for the impact of celebrity fame, measured here by their number of weibo followers, all variables are statistically significant. The impacts are modest however, with each additional endorsement worth an estimated 0.11 newspaper articles/month over time, holding other factors constant. The estimated bump a charity receives in the month following 
initial endorsement is similarly small at around one additional article, ceteris paribus. And celebrities' relative fame level - at least as measured by weibo followers - is predicted to have no impact at all. In the charitable world, it seems that an endorsement from a stand-up comedian like Carrot Top is worth about as much as that from an A-list actor like Brad Pitt: very little.

More important over time is the impact of previous press coverage, which strongly predicts subsequent coverage even in the absence of any celebrity endorsements. For example, newspaper journalists wrote an average of 9.75 articles per month on the China Women's Development Foundation (Zhongguo funü fazhan jijinhui 中国妇女发展基金会) in the year prior to December 2008, when host Sa Beining, actress Lü Liping and academic Yu Dan gave the organisation its first collective endorsement. Despite all this star power and the celebrities' combined 6.5 million weibo followers, in the subsequent year the charity only managed 7.9 articles per month, a drop of almost two articles per month from prior press coverage. Most Chinese charities would be thrilled to receive an average of nearly eight press clippings a month, but it is clear that this level of coverage is based on the charity's previous visibility, not on celebrity endorsements.

Sometimes even multiple simultaneous celebrity endorsements are not enough to drive news coverage. The China Social Welfare Education Foundation Free Lunch Program (Zhongguo shehui fuli jijinhui mianfei wucan gongyi xiangmu 中国社会福利基金会免费午 餐公益项目) was endorsed by six celebrities with a combined 100 million weibo followers (Gao Yuanyuan, Hu Ge, Sha Yi, Wang Baoqiang, Xu Zheng and Zhang Ziyi) in April 2011, but did not receive any additional coverage as a result of their endorsement. Results like this - and the statistical model - demonstrate that celebrity impact is quite weak, especially in the months after the initial press burst fades.

Holding other factors constant, past press coverage is the best predictor of future coverage, regardless of celebrity endorsements. Popular charities continued to be popular, while more obscure charities did not much benefit from the reflected limelight of their endorsers. This, surely, is not the deluge of press coverage that previous literature has led scholars to expect.

The ARIMA time series model, which lines up press coverage for all charities alongside the times of their actual endorsements (averaging newspaper hits when they overlap) provides additional evidence that celebrity endorsements have little effect on press coverage (Table 2). The dependent variable here is similar to that in the pooled panel data, 
which measures the total number of articles each celebrity-endorsed charity receives in the year before and after its first celebrity endorsement. The ARIMA time series model, by contrast, measures the average number of newspaper articles across all targeted charities over the 173 month period (July 1999 to November 2013). The major difference between the two is that the target of interest in the pooled panel data is each charity's individual newspaper coverage, while the time series model concentrates on total coverage in each month. Using a model specification with 2 lags $(2,0,0)$ produces a result where none of the variables of interest have any predicted impact on press coverage at all, controlling for previous coverage. $^{54}$

Table 2: ARIMA $(2,0,0)$ regression of celebrity-endorsement indicators on newspaper coverage

\begin{tabular}{llcc}
\hline Variable & Coefficient & $\begin{array}{l}\text { Estimated Standard } \\
\text { Error (semi-robust) }\end{array}$ & p-value \\
\hline $\begin{array}{l}\text { Total weibo } \\
\text { followers of all } \\
\text { celebrity endorsers } \\
\text { for that month (100k } \\
\text { units) }\end{array}$ & 0.0002 & 0.0008 & 0.770 \\
\hline $\begin{array}{l}\text { Multiple } \\
\text { endorsements }\end{array}$ & 0.1164 & 0.0830 & 0.161 \\
\hline First month & 0.5071 & 0.3396 & 0.135 \\
\hline $\begin{array}{l}\text { Newspaper articles } \\
\text { from 1 month before } \\
(1 \text { lag) }\end{array}$ & $0.6141^{* * *}$ & 0.1179 & 0.000 \\
\hline $\begin{array}{l}\text { Newspaper articles } \\
\text { from 2 months before } \\
(2 \text { lags) }\end{array}$ & $0.2549^{*}$ & 0.1299 & 0.05 \\
\hline Constant & $3.631^{* * *}$ & 1.0932 & 0.001 \\
\hline
\end{tabular}

Note: Estimated standard errors are semi-robust, $\mathrm{t}=173$ months

$* * *, * *$ and $*$ indicate significance at the $0.1 \%, 1 \%$ and $5 \%$ levels

We also tried weighting the models by the perceived reliability of each month's newspaper coverage average. In theory, months with lots of charities represented (and averaged together) have more reliable data than months with just a single representative charity. Ultimately, however, the weighting did not much change the results, and weighted models are not presented here. ${ }^{55}$ Except for lagged past coverage, none of the independent variables have any predicted impact on newspaper coverage. Again, the results suggest that celebrities have very little impact on newspaper coverage, an impact that does not much change with model specifications. No matter how the data are sliced, the evidence presented 
here indicates that future newspaper coverage on charities is predicted best by past coverage, with celebrity endorsement having minimal impact.

\section{Discussion}

Academic discussion of celebrity-led philanthropy has blossomed in recent years, initiating a vigorous discussion between those who see the development as a positive force for relieving social problems and those who argue that celebrities are unaccountable elites who help create and produce inequality. ${ }^{56}$ But what if this is all a tempest in a teapot? What if celebrities simply do not matter very much one way or another? Evidence from China, home of the world's largest media market and an increasingly celebrity-oriented culture, ${ }^{57}$ suggests that partisans on both sides are wrong. For drumming up press coverage, even the most famous Chinese celebrities have minimal impact on even the worthiest causes. This absence of coverage is especially surprising given the relentless pressure censorship authorities put on Chinese media organisations to promote positive coverage of social issues.

We must, of course, acknowledge the limitations of our study. Most previous work on celebrity-endorsed philanthropy has been based in Western societies; in the West, perhaps, celebrities have more impact, although the quantitative study conducted by Thrall et al. suggests otherwise. ${ }^{58}$ We also cannot rule out more direct impact of celebrity-led philanthropy in China. It is possible that celebrity endorsements lead not to media coverage but to increased donations or a flood of volunteers for specific organisations. We have not seen any evidence for this hypothetical impact, but we cannot rule it out. Likewise, we have not evaluated the impact of philanthropic endorsement on the celebrities themselves. A cynic might argue that instead of attracting media coverage for their chosen causes, celebrities only garner more plaudits - and exposure - for themselves. ${ }^{59}$ We have not tested this hypothesis, but it too seems unlikely. Given the fact that celebrities are fundamentally media creations, the fact that they cannot drum up newspaper coverage for society's worthiest causes is quite revealing.

In the end, evidence from China suggests that the increasing scholarly hand wringing about celebrities' impact is misplaced. Rather than being a force for good or a force for ill, Chinese celebrities seem to be no force at all.

\section{Acknowledgements}


This research was supported under Australian Research Council's Future Fellowship funding scheme (FT100100238), and an Early Career Researcher Grant from the University of Technology Sydney. Thanks to Su Gang and Su Xuezhong for assisting with data collection.

\section{Author Biographies}

Jonathan Hassid is an Assistant Professor in the Department of Political Science at Iowa State University and a Postdoctoral Research Fellow at the University of Technology Sydney. He researches the politics of the Chinese news media, and has published in Comparative Political Studies, China Quarterly, Journal of Communication, Asian Survey and elsewhere.

Elaine Jeffreys is an Australian Research Council Future Fellow (FT100100238) and Associate Professor at the China Research Centre, Faculty of Arts and Social Sciences, University of Technology Sydney. Elaine is the author of Sex in China, with Haiqing Yu (2015 Polity); Prostitution Scandals in China: Policing, Media and Society (2012 Routledge) and China, Sex and Prostitution (2012 [2004] Routledge). She is the editor of China's Governmentalities: Governing Change, Changing Government (2011 [2009] Routledge); Celebrity in China, with Louise Edwards (2010 Hong Kong University Press); and Sex and Sexuality in China (2009 [2006] Routledge).

\section{Notes}

1. Tsaliki, Huliaras and Frangonikolopoulos, Transnational Celebrity Activism, back cover.

2. Brockington, "The Production and Construction", 88.

3. Rojek, “"Big Citizen’ Celanthropy”, 127.

4. Bishop and Green, Philanthrocapitalism; http://www.unicef.org/people/people_ambassadors.html. Accessed 12 May 2014.

5. Kapoor, Celebrity Humanitarianism; Nickel, "Philanthromentality".

6. Thrall et al, "Star Power".

7. http://www.unicef.org/people/people_ambassadors.html. Accessed 12 May 2014.

8. Bishop and Green, Philanthrocapitalism, 12.

9. de Waal, “The Humanitarian Carnival”, 52; Rojek, “"Big Citizen' Celanthropy”, 130.

10. Bishop and Green, Philanthrocapitalism

11. Rojek, “'Big Citizen' Celanthropy”, 127.

12. Kapoor, Celebrity Humanitarianism, 1 .

13. Rojek, “"Big Citizen’ Celanthropy”, 139.

14. Kapoor, Celebrity Humanitarianism, 128.

15. Riche and Ponte, "New Actors and Alliances", 66.

16. Riche and Ponte, "Buying Into Development?", 66. 
17. Ibid., 68,81 .

18. Ibid., 82-4.

19. Brockington, "The Production and Construction", 88.

20. Ibid., 95 .

21. Ibid., 100-3.

22. Ibid.

23. Ibid., 102 .

24. McGoey, "The Philanthropic State".

25. Ibid., 110.

26. Bishop and Green, Philanthrocapitalism.

27. McGoey, "The Philanthropic State", 122.

28. Ibid., 112-13. See also http://www.gatesfoundation.org/Media-Center/Press-

Releases/2010/11/Vodacom-gets-US-48-Million-to-Expand-MPesa-Services. Accessed 14 May 2014.

29. Thrall et al, "Star Power", 362.

30. Ibid., 364.

31. Ibid., 369, 374.

32. Ibid., 383.

33. Couldry and Markham, "Celebrity Culture", 403.

34. Bell, "Raising Africa?”; Jeffreys, "Zhang Ziyi”; http://www.huffingtonpost.com/2012/06/15/lance-armstrong-foundation-dopingcharges_n_1598379.html. Accessed 15 June 2014.

35. McGoey, "The Philanthropic State", 109.

36. Wong, Marginalization and Social Welfare.

37. Jeffreys and Sigley, "Governmentality, Governance and China", 14.

38. Watson "Building Social Welfare", 265; Wong, "Privatization of Social Welfare', 311-23.

39. Edwards and Jeffreys, Celebrity in China; Goodman, The New Rich.

40. Zhonghua renmin gongheguo guomin jingji he shehui fazhan ' 95 ', http://cpc.people.com.cn/GB/64184/64186/66686/4494253.html. Accessed 16 June 2014.

41. Zhonghua renmin gongheguo guomin jingji he shehui fazhan di shi, http://www.moc.gov.cn/zhuzhan/jiaotongguihua/guojiaguihua/guojiaxiangguan_ZHGH/2007 09/t20070927_420874.html. Accessed 16 June 2014.

42. Zhonghua renmin gongheguo guomin jingji he shehui fazhan di shiyi, http://news.xinhuanet.com/misc/2006-03/16/content_4309517.htm. Accessed 16 June 2014.

43. Zhonghua renmin gongheguo guomin jingji he shehui fazhan di shier ge, http://www.gov.cn/2011lh/content_1825838.htm. Accessed 16 June 2014.

44. Fitzgerald, "Supporting China's", 75-8. 
45. It bears noting that including the other 155 charities in the analysis does not materially change the results.

46. Hassid, "Safety Valve".

47. Note that data limitations mean we measured all these things at the same time - at the start of data collection in mid-2013. In other words, we do not have measures of celebrities' Baidu hits or weibo followers on the actual dates they endorsed the charities.

48. A high Pearson chi-square statistic indicates substantial overdispersion in the data.

49. Hildebrandt, Social Organizations.

50. On the pressure to produce positive reporting, see the leaked propaganda directives archive hosted at China Digital Times, http://www.chinadigitaltimes.net. See He, Media Control in China, 17, for more on how newspapers that report too many negative stories get punished.

51. The trend line for figures 3 and 4 are quadratic as this better fits the data than a linear trend line, especially in Figure 4.

52. Eighty-three year-old Zhang Ruifang endorsed the Shanghai City Charity Foundation in 2001, but her death in 2012 presumably impacted the number of weibo followers she had amassed at the time of data collection in 2013.

53. Using a GEE population-averaged model produces similar results.

54. Augmented Dickey-Fuller tests indicate the series is stationary. We selected the AR(2) specification based on AIC and SBIC information criteria.

55. Weighted models are available from the authors.

56. Bishop and Green, Philanthrocapitalism; Kapoor, Celebrity Humanitarianism.

57. Edwards and Jeffreys, Celebrity in China.

58. Thrall et al, "Star Power".

59. Kapoor, Celebrity Humanitarianism, 20-1.

\section{Bibliography}

Bell, K. "Raising Africa? Celebrity and the Rhetoric of the White Saviour." PORTAL Journal of Multidisciplinary International Studies 10, no. 1 (2013): 1-24. doi: http://dx.doi.org/10.5130/portal.v3i2.214

Bishop, M., and M. Green. Philanthrocapitalism: How the Rich Can Save the World, and Why We Should Let Them. London: A \& C Black, 2008.

Brockington, D. "The Production and Construction of Celebrity Advocacy in International Development." Third World Quarterly 35, no, 1 (2014): 88-108.

Couldry, N., and T. Markham. "Celebrity Culture and Public Connection: Bridge or Chasm?" International Journal of Cultural Studies 10, no. 4 (2007): 403-421. 
de Waal, A. "The Humanitarian Carnival: A Celebrity Vogue." World Affairs: A Journal of Ideas and Debate (Fall, 2008): 43-55.

Edwards, L., and E. Jeffreys, eds. Celebrity in China, Hong Kong: Hong Kong University Press, 2010.

Fitzgerald, J. “Supporting China's Expanding Non-profit Sector." In Bridging the Trust Divide:

Cultural Diplomacy and Fostering Understanding Between China and the West, edited by $\mathrm{H}$.

Anheier and B. Lorentz, 75-80. Berlin: Stiftung Mercator, 2012.

Goodman, D.S.G., ed. The New Rich in China. Abingdon: Routledge, 2008.

Hassid, J. "Safety Valve or Pressure Cooker? Blogs in Chinese Political Life." Journal of Communication 62, no. 2 (2012): 212-230.

He, Q. Media Control in China [Zhongguo Zhengfu Ruhe Kongzhi Meiti]. New York: Human Rights in China, 2004.

Hildebrandt, T. Social Organizations and the Authoritarian State in China. Cambridge: Cambridge University Press, 2013.

Jeffreys, E. "Zhang Ziyi and China's Celebrity Philanthropy Scandals." PORTAL Journal of Multidisciplinary International Studies 8, no. 1 (2011): 1-21. doi: http://dx.doi.org/10.5130/portal.v3i2.214

Jeffreys, E., and G. Sigley. "Governmentality, Governance and China." In China's Governmentalities: Governing Change, Changing Government, edited by E. Jeffreys, 1-22. Abingdon: Routledge, 2011.

Kapoor, I. Celebrity Humanitarianism: The Ideology of Global Charity. Abingdon: Routledge, 2013.

McGoey, L. "The Philanthropic State: Market-State Hybrids in the Philanthrocapitalist Turn." Third World Quarterly, 35, no. 1 (2014): 109-125.

Nickel, P.M. "Philanthromentality: Celebrity Parables as Technologies of Transfer." Celebrity Studies 3, no. 2 (2012): 164-182.

Riche, L.A., and S. Ponte. "New Actors and Alliances in Development." Third World Quarterly 35, no. 1 (2014): 1-2.

Riche, L.A., and S. Ponte. "Buying Into Development? Brand Aid Forms of Cause-related Marketing." Third World Quarterly, 35, no. 1 (2014): 65-87.

Rojek, C. “"Big Citizen' Celanthropy and Its Discontents.” International Journal of Cultural Studies 17, no. 2 (2014): 127-141.

Thrall, A.T., J. Lollio-Fakhreddine, J. Berent, L. Donnelly, W. Herrin, Z. Pacquette, R. Wenglinski, and A. Wyatt. "Star Power: Celebrity Advocacy and the Evolution of the Public Sphere." The International Journal of Press/Politics 13, no. 4 (2008): 362-385.

Tsaliki, L., C.A. Frangonikolopoulos, and A. Huliaras. Transnational Celebrity Activism in Global Politics. Bristol: Intellect Press, 2011. 
Watson, A. "Building Social Welfare in China: Providing Retirement Incomes in a Transforming Economy." In Rebalancing and Sustaining Growth in China, edited by H. McKay and Song Ligang, 265-287. Canberra: ANU EPress, 2012.

Wong, L. "Privatization of Social Welfare in Post-Mao China." Asian Survey 34, no. 4 (1994): 307325 .

Wong, L. Marginalization and Social Welfare in China. London: Routledge, 1998.

Zhonghua renmin gongheguo guomin jingji he shehui fazhan ' 95 ' jihua he 2010 nian yuanjing mubiao gangyao [The Ninth Five-Year Plan for National Economic and Social Development and Summary of the 2010 Long-term Objectives of the People's Republic of China] (1996) National People's Congress, 7 March.

Zhonghua renmin gongheguo guomin jingji he shehui fazhan di shi ge wunian jihua gangyao [The Tenth Five-Year Plan for National Economic and Social Development of the People's Republic of China] (2001) National People's Congress, 15 March.

Zhonghua renmin gongheguo guomin jingji he shehui fazhan di shiyi ge wunian guihua gangyao [The Eleventh Five-Year Plan for National Economic and Social Development of the People's Republic of China] (2006) National People's Congress, 16 March.

Zhonghua renmin gongheguo guomin jingji he shehui fazhan di shier ge wunian guihua gangyao [The Twelfth Five-Year Plan for National Economic and Social Development of the People's Republic of China] (2011) National People's Congress, 16 March. 
Author copy, prior to publication, 11 September 2014. 